\title{
Brazilian engagement to Asia and the Belt and Road Initiative in 2017: less politics, more trade and investments
}

\section{O Brasil diante da Ásia e da Belt and Road Initiative em 2017: menos política, mais comércio e investimentos}

\section{DOI: $\underline{10.5752 / P .2317-773 X .2017 v 6 . n 1 . p 26}$}

1. Master candidate in Postgraduate Program in International Relations San Tiago Dantas (Unesp, Unicamp, PUC-SP), and researcher at Nucleus of Studies on Foreign Policy of the United States (NEPEU); joao_paulo_apd@hotmail.com Orcid: 0000-0002-4239-3522

2. PhD candidate in Postgraduate Program in International Relations San Tiago Dantas (Unesp, Unicamp, PUC-SP), CAPES Brazil scholarship from National Institute of Science and Technology for studies on the United States (INCT-INEU), researcher at the Center for International Studies and Analyses (NEAI-Unesp) and at the

Center for Studies of Internationa Economic Relations (CERI IE/Unicamp); d.almeidapires@gmail.com Orcid: 0000 0002-7338-1698

3. PhD in Economic Sciences from the State University of Campinas, associate Professor at the Pontifical

Catholic University of São Paulo, PUC-SP, Department of Economics and Postgraduate Program in International

Relations San Tiago Dantas (Unesp,

Unicamp, PUC-SP), and contributing professor at the Graduate Program in Economics of the Federal University of ABC. cecarv@uol.com.br Orcid: $\underline{0000-}$ 0002-2962-9422
João Paulo Nicolini Gabriel ${ }^{1}$

Desirée Almeida Pires ${ }^{2}$

Carlos Eduardo Carvalho ${ }^{3}$

Recebido em: 02/02/2018

Aceito em: 05/03/2018

\begin{abstract}
The paper aims to appreciate Brazilian position in relation to Asia and Belt and Road Initiative (BRI), based on a literature review, journalistic articles on Brazil-Asia relations and official data of the Brazilian economy. Both the former government, headed by Dilma Rousseff, and the current administration, led by Michel Temer, have been facing a troubled political and economic scenario, which negatively impacts on its diplomacy. Although Brazil reaffirmed its commitment with global strategic partnership with China in terms of trade flows, the lack of Brazilian participation on issues of global political nature directly impacts on the way in which Brasilia moved its attention to the BRI and the Asian affairs. The ambitious proportions and objectives of the BRI summed to the rise of a nationalist economic policy of the United States indicate a deepening of several movements that have been altering the international balance of power, which can extend opportunities for Brazil, by means of a cohesive long-term policy for Asia and in a multifaceted way beyond trade.
\end{abstract}

Key-words: 'Brazilian Foreign Policy'; 'Belt and Road Initiative'; 'Asia'; 'geopolitics'; 'China'

\section{RESUMO}

O artigo analisa a posição brasileira em relação à Ásia e a Belt and Road Initiative (BRI), com base em uma revisão da bibliografia e de artigos jornalísticos sobre o tema Brasil-Ásia e de dados oficiais sobre a economia brasileira. Desde os anos finais do governo de Dilma Rousseff, o Brasil enfrenta um cenário político e econômico difícil que afeta sua diplomacia. Embora o Brasil tenha reafirmado seu compromisso com a parceria estratégica global com a China em termos de fluxos comerciais, a participação tímida em questões de natureza política global afeta diretamente a maneira como Brasília atua em relação à BRI e aos assuntos asiáticos. As ambiciosas proporções e objetivos do BRI, somadas ao surgimento de uma política nacionalista dos Estados Unidos, indicam o aprofundamento de processos que estão mudando o equilíbrio internacional de poder, o que pode oferecer oportunidades para o Brasil, por meio de uma política internacional coesa e de longo prazo para a Ásia e de forma multifacetada para além das relações comerciais.

Palavras-chave: Política Externa Brasileira; Iniciativa Belt and Road; Asia; Geopolítica; China 
Introduction

At the beginning of the 20th century, Brazil was considered able to pragmatically formulate a national policy to deal with the transition within the world order, developing a framework of cohesive and planned longterm policies on how to safeguard its national interests in terms of politics, diplomatic, commercial and military areas (CERVO; BUENO, 2015).

Brazilian diplomacy is worldwide known due to some skilled characters who elaborate their country's perception about the international relations. Certainly, the most famous figure is José Maria da Silva Paranhos Junior (1845-1912), known by Baron of Rio Branco, who observed the need for immediately review the strategies to Brazilian international insertion that its diplomatic corps had been pursuing before his tenure as Minister of Foreign Affairs of Brazil from 1902 to 1912 (CERVO; BUENO, 2015). Instead of preserving the focus on European countries - mainly the United Kingdom -, Baron of Rio Branco proposed a more attentive diplomacy to the United States (US) due to the happening changes on the international configurations, which were evidencing the US not only as a global power, but also a potential partner for Brazil in terms of commercial influx and political issues.

The current context presents some lookalike characteristics of those of which Baron of Rio Branco observed on the very beginning of the 20th century: a change in international order is in progress that points to the relative United States decline and the East Asia rise, led by China.

More than being the most populous continent, Asia is the most dynamic region. Countries as India, Japan, Indonesia and specially China are becoming gradually more important within the international politics. The relations among those countries with Brazil are getting each year more important. In 2017, the trade with Asian countries corresponded with 36.16 percent and 32.94 percent of the absolute amount of Brazilian exports and imports respectively. Only China, the largest trade partner of Brazil since 2009, was responsible for 21.8 percent of Brazilian exports in 2017. This percentage is higher than the 16.19 percent absorbed by the South American countries, including the members of MERCOSUR. (BRAZIL, 2018a; BRAZIL, 2018b).

As far as diplomats and scholars are concerned, Brasília cannot keep playing a low-profile diplomacy with its counterparts from Asia. In 2017, the ambassadors of Brazil in New Delhi, Beijing and Tokyo wrote a letter to the national government urging the necessity for more favorable conditions to practice a more substantial policy to Asia (SPEKTOR, 2017). By the same token, the Alexandre de Gusmão Foundation - linked to the Ministry of Foreign Affairs of Brazil - published, in August 2017, the book Os Desafios e Oportunidades na Relação Brasil-Ásia na Perspectiva de Jovens Diplomatas (Challenges and Opportunities in Brazil-Asia Ties in a Perspective of Young Diplomats).

Asia is also a relevant continent to Brazil for geopolitical reasons. Historically, Brasilia seeks an interlocution with the Asian powers to impose itself in the global negotiations through the formation of international arrangements. Solidarity among developing countries in response to the demands 
of the traditional Western powers is a traditional artifice used by Brazilian diplomacy to seek support from Asians in trade negotiations in the World Trade Organization or in the review of international organizations such the International Monetary Fund. For instance, Brazil joins a group of countries to review the United Nations Security Council institutional format with another three members - two of them Asian: Japan and India.

However, the arrangement that calls Brazilian attention at most is the BRICS. The transformation of this initiative from an acronym to a political coordination group is considered the most substantial diplomatic move that Brazil has recently joined.

So, when and why Brazil lost its prominence inside the international arena? During the final years of the Fernando Henrique Cardoso's administration (1995-2002) and especially during the Lula da Silva's terms (20032010), Brazil was considered an emerging economy that played a relevant role in global affairs and strongly supported the formulation of new channels of dialogues with the Asian partners. However, in recent years, Brazilian diplomacy has started to face embarrassing situations like the Brazilian embassy in Japan, in 2015, not paying electricity bills or the absence of a ministerial-level diplomatic mission during the First Forum of the Belt and Road Initiative (BRI), organized by China in May 2017 - something criticized by the Brazilian press due to the fact that countries as such Argentina and Chile sent their own presidents to this meeting (LOPES, 2017a).

Those setbacks on Brazilian international engagement stems from domestic political environment that has affected the ability of Brazilian diplomacy to draw effective long-term strategies to respond to the new signals coming from Asia. If Brazilian diplomacy during Celso Amorim's terms as Minister of Foreign Relations of Brazil was known as haughty and active, what we have seen since Dilma Rousseff's government (20112016) is a Brazilian inability to lead more assertive positions on the global stage and seize the opportunities arising from an international context in transition. Moreover, part of Rousseff's lack of interest in foreign policy issues can be attributed to the beginning of the political and economic crises that lead to her impeachment and still exist.

This paper seeks to demonstrate how Brazil acted diplomatically towards Asia in the year 2017. Brazil, since the beginning of this century, apparently recognized the changes in international configurations, but the internal political conditions difficult to maintain the consolidation of what could become the grand strategy of Brazil for future years. The inability to establish new dialogues and actively take advantage of the opportunities that emerging Asian powers can offer are verifiable even in current diplomatic relations with these countries.

Beyond this introduction, the paper is divided into four parts. The next section takes stock of Brazil's diplomatic engagement with Asia in 2017, marked by a context of domestic political crisis, the section three provides an overview about BRI and the fourth discusses the Brazilian view about BRI. Finally, we present some final considerations about Brazil's diplomacy regarding the formulation of a grand strategy that embraces a cohesive policy to deal with the new interactions of the international arena. 
The recent changes in Brazilian diplomacy and the interest in Asia

Dilma Rousseff's government, inaugurated in 2011, was marked by a gradual retraction of Brazilian participation in the international arena, even in its first two years, when has not faced yet the economic and political crises due to the investigations on corruption that directly reached its government. In this context, Brazil has not demonstrated the leading role abroad, having accumulated a debt with the United Nations in 2015 of approximately US\$ 260 million (CHADE, 2015). The Brazilian press has consistently reproduced that Rousseff was an uncompromising person with little regard for global issues. Yet, in a bureaucratic and institutionalized structure such as Brazilian diplomacy and business interests, it seems far more plausible to justify that the decrease in Brazilian performance abroad was due to the convergence of domestic crises triggering smaller diplomatic ambitions soon after an atypical moment of impressive expectations that marked the Lula da Silva government (2003-2010).

Michel Temer's government, which replaced Rousseff's after the impeachment process in 2016, turns to the mission to recover an economy in recession that saw its GDP shrink by 3.6 percent in 2016, paralyzed investment and severe unemployment. Soon, the jargon of Brazilian foreign policy became "drawing a foreign policy to suit the national interest without ideological commitment" as an attempt to differentiate from Rousseff's left-wing discourse as well as to transmit an image of a government concerned to serve supposed neutral interest as such attracting foreign capitals and expanding trade flows discourse.

The change in perspective from the last governments is more rhetorical only because South-South cooperation has lost ground in official discourse. In fact, the vision about the international insertion of Brazil is much debated, although several aspects are not so well developed within the population, since the issue has become more restricted to academic groups, non-governmental organizations (NGOs) and business groups. Barbosa (2017b) contrasts with the predominant thinking about foreign policy during the Rousseff administration in saying that Brazil should become more interested in the trade issue insofar as it is embedded in global value chains and in seeking to reduce bureaucracy in the process of internalization of international treaties.

The foreign policy of the current government seeks to focus on the interests of Brazil beyond any political ideology, which supposedly would help to bring the focus of its actions abroad to strengthen relations with states that demonstrated important markets consumers for Brazilian products as well as having capitalist classes interested in investing in countries such as Brazil (BARBOSA, 2017a).

If Brazil's choice is to promote the export of products, the Asian market is a natural focus. Commodities have maintained a surplus in the trade balance thanks to the appetite of Asian consumers, who account for 61 percent of the global market (BRAZIL, 2017a). In February 2017, the Brazilian Minister of Foreign Affairs José Serra selected Georges Lamazière as Undersecretary General for Asia and the Pacific, a position which may be considered one of the most strategic divisions within Bra- 
4. According to the Joint Statement and Joint Action Plan prepared by Chinese Prime Minister Li Keqiang's visit to Brazil in 2015, the structuring of the global strategic dialogue between the two countries is fundamental because: "The mechanism of the Global Strategic Dialogue between the two Ministers of Foreign Affairs is an important platform for deepening strategic mutual trust and broadening strategic consensus. In principle, the two parties will mee once a year in one of the two countries, alternately, in order to promote exchange and coordination on the medium and long-term planning of bilateral relations, their respective external policies, as well as the main current world and regional issues margin of multilateral conferences" (free translation from Portuguese). (BRAZIL, 2015a). zilian diplomacy. His mission was to find new manners to strengthen and expand Brazil's relations with the Asian countries mainly in terms of commercial influx. Despite of his brief passage as Minister, Serra delimited the main guidelines of Brazilian foreign policy of the current government in his inaugural speech in 2016. On Asian affairs, he was clear: it is of the utmost importance for Brazil strengthens its relations with Asian partners; in particular, China and India (SERRA, 2016).

This characteristic was maintained even when Aloysio Nunes replaced José Serra. Some of the previous government's foreign policy priorities were somehow maintained with changes on its focus - for example, the setting up of a department inside the Brazil Trade and Investment Promotion Agency (Apex-Brasil) to expand and diversify Brazilian exports to Asian countries (BARBOSA, 2017a).

Furthermore, the global strategic partnership ${ }^{4}$ between Brazil and China is also reflected in the increase in Chinese investments in Brazil. It is interesting to note that this partnership was consolidated in 2012 in order to strengthen the diplomatic relations between them, which since 1993 were strategic partners - the first such relationship between two developing countries. As a result of this approach, the two countries have established several diplomatic channels and important initiatives that bring together technological advances, market opening for their companies, several announcements of partnerships in the mining sectors; oil crude extraction; investments; and industrial and financial cooperation. The China-Brazil Commission of High Level of Agreement and Cooperation (COSBAN) is the main exponent of this ambit because once established in 2004 during Lula da Silva's visit to China, it has established itself as an important channel of mutual consultations on various issues, hoping to increase cooperation and invariably aiding to expand the dialogues about the bilateral tie and international politics. (CORREA; BARBOSA, 2017).

Thus, Brazil came to hold the second position in terms of receiving contributions from China, behind only the United States. By 2017, the Chinese government and entrepreneurs intend to increase the pace of insertion in Brazil - which had already been demonstrated in 2016 with the acquisition of several companies in the energy sector and in the formulation of partnerships in infrastructure projects. Temer's government commemorates the interest of several Chinese state-owned enterprises in entering the Brazilian market for renewable energy, railways, ports, and so on. In the second half of 2017, the Chinese invested approximately US\$ 6.7 billion in Brazil. There is a movement of large inflows of Chinese capital into the Brazilian market, which has lately been very focused on infrastructure sectors such as energy and mining ( 85 percent of the amount confirmed). It should be noted that 73.6 percent of the investments originated from Chinese public-sector companies (BRAZIL, 2018d).

On other Asian countries, the Brazilian government had a more modest agenda focused on investment attraction and expansion of trade flows. President Temer had already been in India and Japan in 2016, and in Russia in 2017. It is important to highlight the meeting between the Brazilian president with Narendra Modi, Indian Prime-Minister, on the 
sidelines of the BRICS Summit of 2017, and Minister Aloysio Nunes' voyage to the ASEAN region in September 2017.

With the convergence of rising commodity prices and a record harvest in 2017, the share of primary products in the Brazilian trade balance accounted for 46.4 percent of exports. China, for the first time, bought a quarter of the total exported by Brazil, with 45 percent of Brazil's soybeans as well as 21 percent of the iron minerals. Therefore, it is notorious why, even though being a president with very low engagement in international affairs, Temer has traveled twice to China - a country that, together with the United States, has been the most visited to date.

While trade with India and members of ASEAN - a regional bloc that MERCOSUR reestablished a dialogue in 2017 that had not occurred since 2009 - are still below expectations, the trade agenda with China presents robust values - Brazilian exports for that country, in 2017, have already surpassed the US\$ 47 billion mark - but some people are concerned about this commercial influx because 86.5 percent of the exported to China is based on commodities (mainly soybeans and iron ore), while 97.3 percent of the US\$ 27.3 billion imported from the Asian country correspond to manufactured goods (BRAZIL, 2017b; BRAZIL, 2017d). Differently from the United States, the second largest importer of Brazilian products, which has an import relation with Brazil based 56.4 percent on manufactured products (BRAZIL, 2018c), that scares some policymakers and economists who see the Chinese appetite for agricultural and mineral product with reticence because it is keeping the economy of Brazil locked in a dangerous dependence of international prices of primary products, despite the signature, in 2015, of a Joint Action Plan for 20152021, between Brazil and China, and ratified the Framework Agreement for the Development of Investment and Cooperation in Productive Capacity (BRAZIL, 2015a). In addition to China's commitment to increasing investment in Brazil, there was a commitment to increase the export of Brazilian manufactured goods to China (SCHERER, 2015).

In the first case, both heads of state discussed the possibility of extending the Preferential Trade Agreement (PTA) between India and MERCOSUR and on issues related to the use of ethanol and the expansion and creation of partnerships in space programs and the aeronautical industry (GABRIEL; CARVALHO, 2017). In the second event, Nunes sought to reinvigorate a dialogue with the members of this regional bloc that recently turned fifty years old and was called by Marcos Galvão, Secretary General of Foreign Relations of Brazil, a natural partner of MERCOSUR (ROMILDO, 2017). The main reasons for Brazilian Minister' visits to Malaysia, Vietnam and Singapore were: to increase trade flows and attract investment with the space left by the US after leaving the Transpacific Partnership (TPP); rekindle the possibilities of an approximation of MERCOSUR with the Asian bloc; and met in Singapore with the ambassadors of Brazil in Singapore, the Philippines, Thailand, East Timor, Myanmar and Indonesia (which accumulates the post with the representation of Brazil in ASEAN) in order to start gathering efforts around a formulation of a more cohesive policy to Asia (BRAZIL, 2017c; RACY, 2017; DIB, 2017). 
With little room for diplomacy due to the troubled domestic politics, Temer went to China to focus on bilateral talks and to participate mainly in forums promoted with entrepreneurs, hoping to demonstrate that his economic policy had begun to produce positive results and Brazil was returning to be attractive to foreign investments. During the international negotiations, Brazil preferred a less emphatic position amidst a moment of tension between India and China because of the diplomatic quarrel in the Donglang plateau and the fact that New Delhi is very reticent with the China-Pakistan Economic Corridor (CPEC), part of the project of the BRI, which runs through the disputed region of Kashmir. It was preferred to avoid taking sides in a controversial episode involving two states, which Brazil sees commercial and investment possibilities (GABRIEL; CARVALHO, 2017; STUENKEL, 2017).

Recently, Brazilian diplomacy has had a discreet participation in the international forums - mainly BRICS. In this grouping of countries that seek to adequate some of the structures of the international system with their demands, Brazil has gone from being a prominent state to a supporting actor overshadowed by India, China and Russia.

Temer's visit to Beijing also aimed to open the Chinese market to Brazil, increasing Brazilian industrialized products and services participation in China, summed to food supply (BRAZIL, 2017f). At the end of this visit, Temer reaffirmed the Brazilian partnership with China on several issues, as commerce, space cooperation, culture promotion and tourism incentive. Moreover, at the BRICS Summit in Xiamen, Temer visited China from 1st to 5th September in a time of great uncertainty due to the suspicions of corruption that were brewing in his government. It was current in the Brazilian press the relationship between the domestic situation of the countries with their performances during the meeting among heads of State: while Narendra Modi, Xi Jinping and Vladimir Putin had support of their populations and presented assertive positions, Michel Temer and Jacob Zuma, South Africa's president at this moment - both at risk of being impeached - presented a low-profile engagement (SACCOMANDI, 2017).

It is debatable whether Temer's diplomacy has resulted in impressive gains for Brazil. Its economic policy has managed to recover the interest of foreign investors due to the ongoing processes of privatization and economic reforms proposed to labor and public pension. The inflow of foreign direct investment and investments in capital markets remained, although the messy political scenario and the downgrade of the ratings assigned to Brazil by risk agencies at the end of the year.

The Belt and Road Initiative

Globalization really began to take on Chinese traits following the election of Donald Trump in the United States. His protectionist platform contrasted with the US' precepts that delimited the international order reigning since the end of World War II. The abrupt withdrawal of the TPP in 2016 was contrasted with Xi Jinping's speech at the Davos Economic World Forum, in 2017, and later by the language used at the Xiamen BRICS Summit that emphasized free trade and multilateralism 
in resolving international disputes - something that Brazil strongly advocates, too (ABDENUR; MUGGAH, 2017).

Trying to obtain some advantages from the new international configuration, Beijing has developed assertive policies in terms of trade and geopolitical projection. There was a need for a reformulation of a China's grand strategy in order to deal with the current moment (ROLLAND, 2017; CLARKE, 2017). In 2017, the 19th Congress of the Chinese Communist Party ratified the process of centralizing the country's views on its engagement in the international system. Since the President Hu Jintao's term (2003-2013), China has been re-evaluating the traditional approach of bide time and build capabilities, which was raised up during Deng Xiaoping's government, to a more strategically foreign policy.

Since 2013, President Xi Jinping begins to draw it with the first announcement of the BRI (ROLLAND, 2017), a long-term project that represents the convergence between national development and China's international assertiveness (PAUTASSO; UNGARETTI, 2017). Not coincidentally, Xi Jinping's speech at the 19th Congress highlighted the BRI as a successful practice that will bring mutual benefits to the Chinese people and to the world's people (XI, 2017). The Chinese Dream will be consolidated by a revision of the international economic and geopolitical structure and the BRI is the most ambitious structure for its consolidation through the passage of a China oriented to the pacific ascent for a state that needs to provide public goods to the world and to project itself as a global power.

$\mathrm{Xi}$ Jinping's grand strategy is his personal mark. Xi apparently does not consider China as a rising power that asks for more room within the global order, but he thinks that his country is able to claim a leading role in terms of geopolitics and it is time to put in practice the return of China after being humiliated by Western powers during the last century. Developing countries tend to increase their diplomatic role in the international system when, along with a period of international economic bonanza, they structure bureaucracies and leaders capable of maintaining assertive long-term policies in order to defend their national interests while seeking to expand their power in the global scenario (FIORI, 2007). The outcomes of the last Chinese Communist Party's Congress reaffirm the claim that China brings together these elements once it is possible to be observed inside the two main plans of its current foreign policy: consolidate itself as a military global power by 2050 and the BRI as tradeoriented approach to internationalize its production surplus, capital and currency and an officially more peaceful, as the Action Plan on the Belt and Road Initiative (2015) describes: "The Belt and Road Initiative is in line with the purposes and principles of the United Nations Charter. It upholds the Five Principles of Peaceful Coexistence: mutual respect for each other's sovereignty and territorial integrity, mutual nonaggression, mutual noninterference in each other's internal affairs, equality and mutual benefit, and peaceful coexistence" (CHINA, 2015).

Beijing has fostered the formulation of an institutional framework of the financial sphere in its orbit. The recent foundations of the AIIB in 2015 and the NDB are somehow part of a context encouraged by China to 
5. The term bandwagoing is used by International Relations analysts to characterize a strategy, adopted by several countries, to approach some great power to use its military or economic power to defend their own national interests from dangerous or international crisis (WALT, 1985) create mechanisms to foster international initiatives without the majority participation of developed countries. This is an apparent response to the mostly Chinese frustrations with the emerging countries' participation within global institutions such as the IMF and the World Bank. However, as Saccomandi (2017) claimed, Chinese political-economic proportions have acted as centripetal forces for attraction international arrangements (e.g. BRICS) and banks developed by emerging countries to the context of Chinese influence. Since BRI was first announced in 2013, financial planning was given to enable the completion of the project. In addition to the AIIB, the Silk Road Fund was created with a capital of approximately US\$ 40 billion which provides only loans with term of investments relatively long and it is mainly funded by the State Administration of Foreign Exchange, China Investment Corporation and Export-Import Bank of China (SILK ROAD FUND, 2017a; 2017b).

Not only are its proportions grandiose, but its design is also ambitious. In May 2017, Xi Jinping announced that it will invest RMB 540 billion to consolidate the infrastructure and digital integration project. The BRI; compared constantly by Western scholars, even with Chinese reticence, to the Marshall Plan developed by the US in the post-World War II era, should be further noted for its ambitions and motivations (STOKES, 2015). What Xi Jinping called the "instrument for a new golden age of globalization" will cost about US\$ 900 billion in total and demonstrates a reversal of China's traditional manner for global insertion that prioritizes the bilateral dialogues to a creation of a Beijing-centered cross-country network which seeks to promote several of its interests throughout the world (PHILLIPS, 2017). In what is called as realist school of International Relations, it is possible to affirm that the BRI is luring other countries to adopt a strategy of bandwagon ${ }^{5}$ towards China, since Beijing has tacitly proposed to occupy a space left by the United States due to the nationalist politics of Trump - cases to exemplify this statement are not lacking: from Xi Jinping seeking to couple the investments of the BRI with the Juncker's Investment Plan to recover European Union's economy or the praise that the Chinese project received from some heads of State (PHILLIPS, 2017; TZOGOPOULOS, 2017).

Kynge (2017) points out that the Chinese are aware of how dangerous the initiative is in passing through unstable localities that suffers with actions perpetrated by jihadists and separatist movements - for example Pakistan, Uzbekistan and Myanmar. However, attempts are being made to overcome such difficulties because Beijing needs to establish routes for the Middle Eastern oil's transporting that avoid the use of the Strait of Malacca - the port at Gwadar in Pakistan is part of this context.

China's official speech has convincing arguments. According to the Asian Development Bank (2017), the Asia-Pacific region needs infrastructure investments of roughly US\$ 26 trillion by 2030 to overcome its persistent social woes such as the fact that there are "over 400 million people still lacking electricity, 300 million without access to safe drinking water, and about 1.5 billion lacking access to basic sanitation". The General-Secretary of United Nations António Guterres reinforced this idea, during the Belt and Road Forum, when he pitched China as pillar 
of multilateralism able to help the other countries to manage the social issues by developing initiatives as the BRI (GUTERRES, 2017). Therefore, BRI would be a measure of China to pass to its neighborhood an image of public goods provider and that it is willing to strengthen international economic prosperity and the promotion of peace and development. Likewise, there is Beijing's interest in integrating and improving the economy of autonomous regions which cope with separatist movements and social issues such as Tibet, Inner Mongolia and Xinjiang.

The Brazilian view of BRI

Among Brazilians, the question of what China represents in the current global scenario seems to have been resolved. Beijing is for the world a new factor in redefining geopolitical configurations. The 19th Congress of the Chinese Communist Party was perhaps the one that most called attention from the epistemic community and Brazilian newspapers. Left-wing magazine Carta Capital linked the Chinese leader Xi Jinping to Mao Zedong for having his name and thinking about Chinesestyle socialism included in the Communist Party's statute - something his two predecessors, Hu Jintao and Jiang Zemin, do not have. The centerright newspaper Folha de S. Paulo and the conservative O Estado de S. Paulo replicated the view exposed by the magazine The Economist by citing Xi Jinping as a strong leader who apparently did not appoint a successor in the Congress and seeks to rebuild China's role as a global power through its economic policies and measures for the centralization of power as the fight against corruption - seen with some reticence by some who see it as a strategy to curb political enemies.

$\mathrm{Xi}$ Jinping has been relying on the BRI as the main brand of its foreign policy. Brazilians are aware of the proportions of this project: it encompasses more than 60 countries, one third of the global GDP and 65 percent of the world's population (ABDENUR; MUGGAH, 2017). Its six land corridors and the sea route mean more than an infrastructure project: they are a tool for the internationalization of capital, products and mainly the Chinese renminbi ${ }^{6}$, for the three continents covered: Africa, Asia, and Europe. Observing the rebirth of China as a global power, Brazil needs to act as such Marco Polo to seek greater interchange with the possibilities afforded by the Beijing-led infrastructure project (JANK, 2015).

In Brazil, the BRI, popularly so-called Silk Road, seems to be a concrete proposal to configurate a change from the current center of global power to a sinocentric reality (STUENKEL, 2014). What draw the attention of Brazilians most about this initiative is: I) how China will deal with issues that traditionally seek to avoid positioning itself, such as the Islamic fundamentalism that operates widely in Central Asia and in Pakistan; II) how will the financing of projects covered by BRI be made, something that can directly relate to Brazil. It is noted how China sees the importance of expanding its international insertion as it needs to find new routes and partners to avoid future challenges.

Another issue observed by Brazilian academics and diplomats is how China will deal with the geopolitical implications that BRI can
6. In the Action Plan on the Belt and Road Initiative (2015), Beijing's interest in expanding the use of RMB in other countries is shown in this citation: "We will support the efforts of governments of the countries along the Belt and Road and their companies and financial institutions with good credit-rating to issue Renminbi bonds in China. Qualified Chinese financial institutions and companies are encouraged to issue bonds in both Renminbi and foreign currencies outside China, and use the funds thus collected in countries along the Belt and Road". 
bring. Although viewed as a way for China to shed its output by opening new markets and boosting the liberation of credit lines, Beijing's assertive insertion in the spheres comprising Central Asia and South Asia invariably enables staggering rivalries with other powers that are also part of the BRICS - India and Russia (STOKES, 2017; PAUTASSO, UNGARETTI, 2017). The Indian discontent at the BRICS Summit in Goa, 2016, with Beijing's reticent stance on condemning terrorist groups which are based in Pakistan, was visible due to the fact that Chinese government did not want to make a move which can trigger a directly misunderstand with a major partner in the BRI project (GABRIEL; CARVALHO, 2016). Likewise, Moscow shows little interest in seeing its area of influence be disputed with Beijing. As BRICS countries have continued to show certain incompatibility of views on some points, Brazil fears that there is less possibility of convergence among members of this group and invariably lead to a fragmentation of interests with India, engaging the US and Russia in a competition for the Central Asia.

Beijing seems to have understood the need to defend BRI's infrastructure projects from potential hurdles. At the last BRICS summit, the Indians had a great victory when they were nominally quoted jihadist organizations working in the Asian context, something that did not count on the traditional Chinese reticence in the subject (GABRIEL; CARVAL$\mathrm{HO}, 2017)$. However, there is a staggering of tensions between the governments of Xi Jinping and Narendra Modi, something that Brazil finds uninteresting for the BRICS institutional advance. India deliberately boycotted the First BRI Forum because it believed that CPEC was a breach of sovereignty. It must be said that the disagreements between the two Asian powers are observed with caution by Brasilia since its diplomats and leaders do not intend to take sides in this matter involving two important partners of its foreign policy.

Since India's position reverberated internationally with the boycott on the Forum, it should be noted that criticisms of the way in which BRI is planned to be financed have had some repercussions in Brazil. The emphatic critic came from India was not only because the CPEC passes through Kashmir region, but also due to the fact that India government believes that China is creating an international Sino-dependence since BRI is based on loans and financings which can make some less-developed countries indebted (CHAUDHURY, 2017).

The second point cautiously observed by Brazilians - and who can directly link their state to BRI - is the way in which this bold proposal will be financed. Beijing's option to fund infrastructure projects and opening new diplomatic channels and markets for its enterprises rather than maintaining a policy focused on expanding its international reserves by acquiring the sovereign bonds from countries as such the United States comes at a price. In this sense, the most striking feature of Brazil is the possibility that the NDB will be directly involved in fostering projects that can invariably assist in the completion of BRI (ABDENUR; MUGGAH, 2017). The Chinese infrastructure megaproject began to re-shape the sense of the Bank developed under BRICS (ABDENUR, 2017). 
In this sense, regarding the Belt and Road Initiative, NDB's Vice President Chief Financial Officer, Leslie Maasdorp, stated that the Bank is not competing with the Asian Infrastructure Investment Bank, instead, it can work together with the AIIB, the China Development Bank and the Silk Road Fund (NEW DEVELOPMENT BANK, 2016a). According to Vladimir Putin, cooperation by NDB could promote projects associated with BRICS' countries integration. The Russian president proposed, during a meeting of heads of state of the Eurasian Economic Union in 2015, the integration among this Union, the Silk Road Economic Belt and the ASEAN in order to guarantee a basis for the Big Eurasian Partnership. Moreover, Putin affirmed that "[t] he BRICS cooperation potential may also be used to implement this initiative" (PUTIN, 2016).

In the beginning of 2017, the NDB's president, K.V. Kamath, stated that, after raised funds in renminbi in 2016, the bank was planning raise funds in India's currency, the rupee, to finance infrastructure projects approved by the group in order to contribute with economic growth and sustainability, since BRICS countries are drivers of global economic growth. During his testimony regarding the importance of finance those projects, Kamath highlighted the relevance of Belt and Road Initiative: economic program that benefits those countries involved, approaching them and promoting economic activities in the region (KAMATH, 2017).

However, the role of NDB, as well as AIIB, is minor when compared to the Chinese banks, according to estimates: US\$ 110 billion from China Development Bank, US\$ 150 billion from the four biggest stateowned commercial banks in China, against US\$ 2 billion from NDB and US\$ 2 billion from AIIB (amount that add up equals to the reserves from Silk Road Fund) (WILDAU; MA, 2017). Likewise, Xi Jinping has announced, throughout 2017, robust credit lines in renminbi to assist in the realization of BRI projects. In addition to the announced cooperation between the China Development Bank with Russian entities for the creation, in July 2017, of funds to facilitate the contraction of loans in ruble and renminbi (RT, 2017), Plubell and Liu (2017) said that "China would inject additional RMB100 billion capital into Silk Road Fund and would encourage Chinese financial institutions to establish renminbi denominated outbound investment funds with a total value of RMB 300 billion". Therefore, it can be noted that China foments a manner to incentive the use of renminbi while announcing the necessity of creating possibilities to consolidate the projects being developed in countries without ways to afford them as such Tajikistan and Kirgizstan.

Although it received little attention in the political debate and in society in general, the BRI's creation has reverberated within the Brazilian academy and press as a key factor in shaping global geopolitics, which allows to understand the reasons for widespread criticism of the way in which the current government has come to understand and plan strategies in this context. The lack of a cohesive foreign policy for Asia runs through the movements given by Brasilia about BRI in comparison to the engagement of other Latin American countries.

In September 2017, the Foreign Minister of China Wang Yi tried to calm down the Latin Americans about BRI's impact on trade relations 
with China. At first view, the Chinese initiative excludes the American continent from its scope. Some local leaders feared the impact that this context could have on their trade relations with the Asian country that is an important trading partner. According to the Chinese minister, during a visit to Panama, BRI indirectly would favorably impact the export of these countries once the market in Eurasia would gradually become more harmonized and interconnected (CHINA, 2017) - an affirmation reinforced during the China-CELAC Forum Annual Meeting 2018, when the Chinese Foreign Minister claimed:

[...] China and CELAC agreed to jointly build the Belt and Road. As China and other countries work together on the Belt and Road Initiative, LAC [Latin American and Caribbean] countries cannot be absent and should be a meaningful part of it. The ancient Maritime Silk Road had once connected us across the Pacific Ocean. Now in the 21st century, China stands ready to work with LAC countries to revitalize it. Collaboration in this process will create greater space, market as well as resources and means for the development of LAC countries. During the meeting, the Foreign Ministers issued a special declaration on supporting and participating in the Belt and Road Initiative. It means that with the second Ministerial Meeting, this visionary Initiative put forward by President Xi Jinping has been extended to Latin America and the Caribbean, and become the largest and most welcomed platform for international cooperation spanning all continents and oceans. It is also the most important public goods that China provides to the world (WANG, 2018).

The Chilean and Argentinean proactivity, for instance, with respect to the planning of strategies for BRI, leaves the Brazilians apprehensive with the capacity of Brasilia to maintain a prominent role in relation to the other countries of the region within the international scope (GABRIEL; CARVALHO, 2017). Although Brazil is a prominent trading partner of China, there is much room for Brazilian diplomacy to explore regarding the elaboration of a long-term policy with an eye to preparing for the new reconfigurations of the international system. Brazilian engagement in Asia is necessary for expand and diversify trade partnerships - opening space for export manufactured products from Brazil.

Final considerations

The Brazilian tradition of guiding its foreign policy by pragmatism and a quick understanding of the alternations in international configurations has stumbled in an inability of Brasilia to define itself politically. Since the last Rousseff's government and the current Temer's administration, the coexistence of political and economic crisis hampers the formulation of national strategies for greater engagement within the new configurations of the international system. Therefore, Brazilian diplomacy during 2017 is mainly based on the disorganization of the country's internal political scenario that invariably reduced the negotiating capacities of the diplomatic delegations since the federal government was focused on the corruption scandals that hit political parties in Brazil - including the one of President Temer - and on the difficulty in approving structural reforms in labor laws, social security and the tax system.

The scarce Brazilian maneuvering space to negotiate at the international level has been demonstrated in Brazil's blurred diplomacy in 
BRICS and its inability to react promptly to new global interactions; as well as seeking to diversify their exporting patterns.

Considering that Brazil's current foreign policy is geared towards increasing trade flows, BRI is something to be looked at with attention: this project is a catalyst for current geopolitical changes and the establishment of new dynamics within international relations (ABDENUR, 2017).

As the Asian scenario consolidates as a consumer market of rising purchasing power, Brazil has begun a project to include its companies in that context, with an intuition to increase the value added of its export agenda. The impossibility of greater attention to the outside has jeopardized the development of this practice and consequently Brazil continues to fear the advances of Chinese companies within the MERCOSUR, which is an important destination of Brazilian exports of manufactured products. It is important to note that there is a reticence in Brazil regarding the Chinese advance in the Brazilian export tariff since, compared to powers like the United States, Beijing has a clear preference for commodities.

Although Brazil and China reaffirm their global strategic partnership with the increasing in terms of trade flows, Brasília has been acting much less than expected in expanding its ties with the Asian scene. Brazil sent a very small delegation, commanded by the Secretary for Strategic Affairs Hussein Ali Kalout, to the $1^{\text {st }}$ Forum of Belt and Road Initiative, in May 2017. This exemplifies the divergence between Brazil's aspirations as a global power and its lackluster diplomacy in terms of answering promptly to the new global trends. Latin American countries, such as Argentina and Chile, were represented by their respective presidents at the same event (ABDENUR, 2017). For example, the governmental program of exchange of Brazilian students abroad, Ciências Sem Fronteiras $^{7}$ has more participants studying in Hungary than in China (BRAZIL, 2015b; LOPES, 2017).

BRI offers many opportunities for a Latin American power. However, in order to act properly and take advantage of this initiative, Brazil must prepare itself beforehand. The formulation of a cohesive policy for Asia must be thought of in the long term and in a multifaceted way - not only by highlighting the surplus of the trade balance. BRI offers several possibilities to increase the ties among Brazil and China and the Eastern hemisphere has already shown its willingness to open new channel for interaction with States that are not part of BRI - the Chinese idea of making the city of Macao a center for improving China's relation with Portuguese-speaker countries (BARBOSA, 2017c). Brazil ought to focus more emphatically on BRI. During the next meetings organized about BRI, there is a need for greater ministerial engagement and discussion with business sectors and civil society organizations. Not only with increasing trade flows should Brazil seek to exploit relations with China, BRI has geopolitical implications that can invariably change the global balance of power (ABDENUR, 2017; RIBEIRO; SCHUTTE, 2017).
7. On this issue it is worth emphasizing that President Rousseff sought to emphasize educational exchange programs as the main exponent of her foreign policy. During the joint statement between Brazil and China in 2012, the issue appears prominent in China's promise to offer 200 scholarships annually for Brazilians to be sent to their country. (BRAZIL, 2012) 
References

ABDENUR, Adriana Erthal. A Nova Rota da Seda: Oportunidades e Desafios para o Brasil, 25 out. 2017. In: A China do Século XXI: Oportunidades para o Brasil, 2017, Rio de Janeiro: Escola de Guerra Naval. Disponível em: <https://www.egn.mar.mil.br/eventos/seminariochina/palestras/Palestra\%20Adriana\%20Abdenur_25Out17.pdf>. Acesso em 17 dez. 2017.

ABDEnUR, A.E; MUGGAH, R. A Nova Rota da Seda e o Brasil. Le Monde Diplomatique. 2017. Disponível em: <https://diplomatique.org.br/a-nova-rota-da-seda-e-o-brasil/>. Acesso em 17 dez. 2017.

ASIAN DEVELOPMENT BANK. Meeting Asia's Infrastructure needs. Mandaluyong City, Philippines: Asian Development Bank, 2017

BARBOSA, R. A Política Externa do Governo Temer. O Estado de S.Paulo. 2017a. Disponível em: $<$ http://opiniao.estadao.com.br/noticias/geral,a-politica-externa-do-governo-temer,70001664323>. Acesso em 17 dez. 2017.

BARBOSA, R. A nova superpotência. O Estado de S.Paulo. 2017b. Disponível em: <http://opiniao.estadao.com.br/noticias/geral,a-nova-superpotencia,70002099388>. Acesso em $17 \mathrm{dez} .2017$.

BARBOSA, R. A volta da China como grande potência. O Estado de S.Paulo. 2017c.Disponível em: <http://opiniao.estadao.com.br/noticias/geral,a-volta-da-china-como-grande-potencia,70001884775>. Acesso em 17 dez. 2017.

BRAZIL. Ministry of Foreign Relations. 2012. Comunicado Conjunto entre Brasil e China Rio de Janeiro, 21 jun. [Portuguese]. Disponível em: < http://www.itamaraty.gov.br/pt-BR/ notas-a-imprensa/3073-comunicado-conjunto-entre-brasil-e-china-rio-de-janeiro-21-de-junhode-2012>. Acesso em 17 dez. 2017

BRAZIL. Ministry of Foreign Relations. 2015a. Visit of the Prime Minister of China, Li Keqiang, to Brazil - Joint Statement and Joint Action Plan - Brasilia, May 19, 2015 [Portuguese]. Disponível em: <www.itamaraty.gov.br/en/press-releases/12219-visit-of-the-prime-ministerof-china-li-keqiang-to-brazil-joint-statement-and-joint-action-plan-brasilia-may-19-2015-portuguese>. Acesso em 17 dez. 2017.

BRAZIL, Ministry of Education. 2015b. Programa Ciências sem Fronteiras, Bolsistas pelo Mundo. Dez. 2015. Disponível em: < http://www.cienciasemfronteiras.gov.br/web/csf/bolsistas-pelo-mundo?p_p_id=mapabolsistasportlet_WAR_mapabolsistasportlet_INSTANCE_ Y7eO\&p_p_lifecycle $=0 \&$ p_p_state $=$ normal\&p_p_mode $=$ view $\&$ p_p_col_id $=$ column-2\&p_p_ col_count $=1 \&$ codigoArea $=\&$ tituloArea $=$ Todas $\&$ sigla Modalidade $=\&$ nomeModalidade $=$ Tod as>. Acesso 5 jan. 2018

BRAZIL, Ministry of Agriculture. 2017a. Ásia é o mercado com maior potencial para expandir exportações do agro brasileiro. 31 jul. 2017, Disponível em: <http://www.agricultura.gov. $\mathrm{br} /$ noticias/asia-e-o-mercado-com-maior-potencial-para-expandir-exportacoes-brasileiras-doagro>. Acesso em 17 dez. 2017.

BRAZIL. Ministry of Industry, Foreign Trade and Services. 2017b. Exportações, Importações e Balança Comercial - Parceiro: China. Disponível em: <http://www.mdic.gov.br/comercioexterior/estatisticas-de-comercio-exterior/comex-vis/frame-pais?pais=chn $>$. Acesso em $17 \mathrm{dez}$. 2017.

BRAZIL. Ministry of Foreign Relations. 2017c. Viagem do ministro Aloysio Nunes Ferreira ao Sudeste Asiático. Disponível em: <http://www.itamaraty.gov.br/pt-BR/notas-aimprensa/17380-viagem-do-ministro-aloysio-nunes-ferreira-a-malasia-singapura-e-vietna $>$. Acesso em 17 dez. 2017.

BRAZIL. Ministry of Foreign Relations. 2017d. Intercâmbio Comercial com o Brasil e Comércio Exterior. Disponível em: <https://investexportbrasil.dpr.gov.br/arquivos/IndicadoresEconomicos/web/pdf/INDChina.pdf>. Acesso em 17 dez. 2017.

BRAZIL. Ministry of Industry, Foreign Trade and Services. 2018a. Exportações, Importações e Balança Comercial - Comex Vis: Continentes e Blocos: América do Sul. Disponível em: $<$ http://www.mdic.gov.br/comercio-exterior/estatisticas-de-comercio-exterior/comex-vis/ frame-bloco?bloco=america_do_sul>. Acesso em 31 jan. 2018.

BRAZIL. Ministry of Industry, Foreign Trade and Services. 2018b. Exportações, Importações e Balança Comercial - Comex Vis: Continentes e Blocos: Ásia (Exclusive Oriente Médio). Disponível em: <http://www.mdic.gov.br/comercio-exterior/estatisticas-de-comercio-exterior/ comex-vis/frame-bloco?bloco=asia_exclusive_oriente_medio $>$. Acesso em 31 jan. 2018. 
BRAZIL. Ministry of Industry, Foreign Trade and Services. 2018c. Exportações, Importações e Balança Comercial - Parceiro: Estados Unidos. Disponível em: < http://www.mdic.gov.br/ comercio-exterior/estatisticas-de-comercio-exterior/comex-vis/frame-pais?pais=usa $>$. Acesso em 31 jan. 2018.

BRAZIL. Ministry of Planning, Budget, and Management. 2018d. Boletim Bimestral Sobre Investimentos Chineses no Brasil - no ${ }^{\circ}$. Disponível em: $<$ http://www.planejamento.gov.br/noticias/planejamento-divulga-boletim-de-investimentos-chineses-no-brasil>. Acesso em 19 jan. 2018.

CERVO, A; BUENO, C. História da Política Externa do Brasil. Brasília: Editora UnB, 2015.

CHADE, J. Dívida do Brasil na ONU aumenta em 52\% e chega a R $\$ 781$ milhões. O Estado de S.Paulo. 2015. Disponível em: <http://internacional.estadao.com.br/blogs/jamil-chade/dividado-brasil-na-onu-aumenta-em-52-e-chega-a-r-781-milhoes/>. Acesso em 17 dez. 2017.

CHAUDHURY, D.R. China may put South Asia on road to debt trap. Economic Times. 2017. Disponível em: <https://economictimes.indiatimes.com/news/politics-and-nation/china-mayput-south-asia-on-road-to-debt-trap/articleshow/58467309.cms>. Acesso em 17 dez. 2017.

CHINA. The State Council of the People's Republica of China. 2015. Action plan on the Belt and Road Initiative. 2015. Disponível em: < http://english.gov.cn/archive/publications/2015/03/30/ content_281475080249035.htm>. Acesso em $17 \mathrm{dez} .2017$.

CHINA. Ministry of Foreign Affairs of People's Republic of China. 2017. Wang Yi: The Belt and Road Initiative Becomes New Opportunity for China-Latin America Cooperation. 2017. Disponível em: <http://www.fmprc.gov.cn/mfa_eng/zxxx_662805/t1494844.shtml>. Acesso em 17 dez. 2017.

CLARKE, M. The Belt and Road Initiative: China’s New Grand Strategy?. Asia Policy, v. 24, n.1, 2017, p. 71-79.

CORREA, G.F.; BARBOSA, P.H.B. Uma Tentativa Brasileira de Entender o Funcionamento do Governo e do Setor Privado da China. In: BARBOSA, P.H.B. Os Desafios e Oportunidades na Relação Brasil-Ásia na Perspectiva de Jovens Diplomatas. Brasília: FUNAG, 2017, p.21-64.

DIB, A.C. Brasil mira a Asean, bloco formado por dez países e comércio exterior de US $\$ 2,2$ trilhões. Comex do Brasil. 2017. Disponível em: $<$ https://www.comexdobrasil.com/brasil-mira-asean-blocoformado-por-dez-paises-e-comercio-exterior-de-us-22-trilhoes/>. Acesso em 17 dez. 2017.

FIORI, J.L. O Poder Global e a Nova Geopolítica das Nações. São Paulo: Boitempo, 2007.

GABRIEL, J.P.N.; CARVALHO, C.E. A Índia no Brics, após Goa e Trump. Valor Econômico. 2016. Disponível em: <http://www.valor.com.br/opiniao/4793911/india-no-brics-apos-goa-etrump>. Acesso em 17 dez. 2017.

GABRIEL, J.P.N.; CARVALHO, C.E. O BRICS e o complexo jogo asiático. Valor Econômico. 2017. Disponível em: <http://www.valor.com.br/opiniao/5118688/brics-e-o-complexo-jogoasiatico >. Acesso em $17 \mathrm{dez} .2017$.

GUTERRES, A. Remarks at the opening of the Belt and Road Forum.2017. Disponível em: $<$ https://www.un.org/sg/en/content/sg/speeches/2017-05-14/secretary-general\%E2\%80\%99sbelt-and-road-forum-remarks>. Acesso em 17 dez. 2017.

JANK, M. A 'nova rota da seda' e o Brasil. Folha de S.Paulo. 2015. Disponível em: $<\mathrm{http}: / / \mathrm{m}$. folha.uol.com.br/colunas/marcos-jank/2015/05/1623761-a-nova-rota-da-seda-e-o-brasil.shtml>. Acesso em 17 dez. 2017.

KAMATH, K. V. New Bank aims to double loans. NDB. 2017. Disponível em: <https://www. ndb.int/media/new-bank-aims-double-loans/>. Acesso em 17 dez. 2017.

KYNGE, J. How the Silk Road plans will be financed. Financial Times.2017. Disponível em: $<$ https://www.ft.com/content/e83ced94-0bd8-11e6-9456-444ab5211a2f >. Acesso em 17 dez. 2017.

LOPES, D.B. 2017, Brazilian Malaise in the 'Asian Century'. The Diplomat.2017. Disponível em: <https://thediplomat.com/2017/09/brazilian-malaise-in-the-asian-century/>. Acesso em 17 dez. 2017.

NEW DEVELOPMENT BANK. BRICS bank readies debut bond issue for clean energy projects. 2016. Disponível em: <https://www.ndb.int/media/brics-bank-readies-debut-bond-issueclean-energy-projects/>. Acesso em $17 \mathrm{dez} .2017$.

NEW DEVELOPMENT BANK. About us. 2017. Disponível em: <https://www.ndb.int/aboutus/essence/history/>. Acesso em $17 \mathrm{dez} .2017$.

PAUTASSO, D.; UNGARETTI, C.R. A Nova Rota da Seda e a Recriação do Sistema Sinocêntrico. Estudos Internacionais, v.4, n.3, 2017, p.25-44. 
PHILLIPS, T. The \$900bn question: What is the Belt and Road initiative?. The Guardian.2017. Disponível em: <https://www.theguardian.com/world/2017/may/12/the-900bn-questionwhat-is-the-belt-and-road-initiative>. Acesso em $17 \mathrm{dez} .2017$.

PLUBELL, A.M.; LIU, S. A Snapshot of Renminbi Internationalization Trends Under One Belt One Road Initiative. 2017. Disponível em: <https://www.empea.org/app/uploads/2017/10/ Snapshot-of-Renminbi-Internationalization-Trends-Under-One-Belt-One-Road-Initiative.pdf $>$. Acesso em 17 dez. 2017.

PUTIN, V. As the NDB gets stronger, its output will only increase - Putin. 2016. Disponível em: $<$ https://www.ndb.int/media/ndb-gets-stronger-output-will-increase-putin/>. Acesso em $17 \mathrm{dez} .2017$.

RACY, S. Mercosul quer lugar deixado por Trump no comércio com bloco asiático. O Estado de S.Paulo. 2017. Disponível em: <http://cultura.estadao.com.br/blogs/direto-da-fonte/mercosulquer-lugar-deixado-por-trump-no-comercio-com-bloco-asiatico/>. Acesso em $17 \mathrm{dez} .2017$.

RIBEIRO, V.L.; SCHUTTE, G.R., Transformações exigem política externa ativa: a nova Rota da Seda. Carta Capital. 2017. Disponível em: <https://www.cartacapital.com.br/blogs/blog-do-grri/ transformacoes-exigem-politica-externa-ativa-a-nova-rota-da-seda >. Acesso em 17 dez. 2017.

ROLLAND, N. China's Eurasian Century? Political and Strategic Implications of the Belt and Road Initiative. Journal of Democracy v.28, nº, 2017, p.170-174

ROMILDO, J. Brasil quer promover comércio entre Mercosul e Sudeste Asiático. Agência Brasil. 2017. Disponível em: <http://agenciabrasil.ebc.com.br/economia/noticia/2017-08/brasilquer-promover-comercio-entre-mercosul-e-sudeste-asiatico >. Acesso em 17 dez. 2017.

RT. Russia \& China sign \$10bn investment fund to ease ruble-yuan settlements. 2017. Disponível em: <https://www.rt.com/business/395256-russia-china-investment-fund/>. Acesso em 17 dez. 2017.

SACCOMANDI, H. BRICS é cada vez mais o grupo da China. Valor Econômico. 2017. Disponível em: <http://www.valor.com.br/politica/5103530/brics-e-cada-vez-mais-o-grupo-dachina>. Acesso em 17 dez. 2017.

SCHERER, A.L.F. A nova estratégia de projeção geoeconômica chinesa e a economia brasileira. Revista Paranaense de Desenvolvimento-RPD, v. 36, nº. 129, 2015, p. 35-51.

SERRA, J. Discurso por ocasião da cerimônia de transmissão de cargo.2016. Disponível em: $<$ http://www.itamaraty.gov.br/pt-BR/discursos-artigos-e-entrevistas/ministro-das-relacoesexteriores-discursos/14038-discurso-do-ministro-jose-serra-por-ocasiao-da-cerimonia-de-transmissao-do-cargo-de-ministro-de-estado-das-relacoes-exteriores-brasilia-18-de-maio-de-2016>. Acesso em 17 dez. 2017.

SILK ROAD FUND. 2017a. About us.2017. Disponível em: <http://www.silkroadfund.com.cn/ enweb/23775/23767/index.html>. Acesso em 17 dez. 2017.

SILK ROAD FUND. 2017b. Investment Managements. 2017. Disponível em: <http://www. silkroadfund.com.cn/enweb/23798/23768/index.html>. Acesso em 17 dez. 2017.

SPEKTOR, M. Começou o embate pela nova diplomacia do Brasil na Ásia. Folha de S.Paulo. 2017. Disponível em: <http://www1.folha.uol.com.br/colunas/matiasspektor/2017/08/1906675comecou-o-embate-pela-nova-diplomacia-do-brasil-na-asia.shtml>. Acesso em 17 dez. 2017.

STOKES, J. China’s Road Rules. Foreign Affairs.2015. Disponível em: $<$ https://www.foreignaffairs.com/articles/asia/2015-04-19/chinas-road-rules>. Acesso em 17 dez. 2017.

STUENKEL, O. BRICS e o futuro da ordem global. São Paulo: Paz e Terra, 2017a

STUENKEL, O. What to look out for in the run-up to the 9th BRICS Summit in Xiamen. PostWestern World. 2017. Disponível em: < http://www.postwesternworld.com/2017/05/18/bricssummit-xiamen/>. Acesso em 17 dez. 2017.

STUENKEL, O. China's Silk Road Fund: Towards a Sinocentric Asia. Post-Western World. 2014. Disponível em: <http://www.postwesternworld.com/2014/11/21/chinas-towards-sinocentric/>. Acesso em 17 dez. 2017.

STUENKEL, O. Post-Western world: How emerging powers are remaking global order. Malden: Polity Press, 2016.

TEMER, M. Discurso do Presidente da República, Michel Temer, durante reunião ampliada dos Chefes de Estado e de Governo do Brics - Xiamen-China. 2017a, Disponível em: $<$ http://www.itamaraty.gov.br/pt-BR/discursos-artigos-e-entrevistas-categoria/presidenteda-republica-federativa-do-brasil-discursos/17411-discurso-do-presidente-da-republica-micheltemer-durante-reuniao-ampliada-dos-chefes-de-estado-e-de-governo-do-brics-xiamen-china4-de-setembro-de-2017>. Acesso em 17 dez. 2017. 
TEMER, M. Discurso do Presidente da República, Michel Temer, durante reunião reduzida dos Chefes de Estado e de Governo do Brics - Xiamen-China. 2017b. Disponível em: $<$ http://www.itamaraty.gov.br/pt-BR/discursos-artigos-e-entrevistas-categoria/presidente-darepublica-federativa-do-brasil-discursos/17412-discurso-do-presidente-da-republica-michel-temer-durante-reuniao-reduzida-dos-chefes-de-estado-e-de-governo-do-brics-xiamen-china-4-desetembro-de-2017>. Acesso em 17 dez. 2017.

TEMER, M. Discurso do Presidente da República, Michel Temer, durante cerimônia de abertura do Fórum Empresarial do Brics - Xiamen-China. 2017c. Disponível em: $<$ http://www. itamaraty.gov.br/pt-BR/discursos-artigos-e-entrevistas-categoria/presidente-da-republicafederativa-do-brasil-discursos/17382-discurso-do-presidente-da-republica-michel-temer-durante-cerimonia-de-abertura-do-forum-empresarial-do-brics-xiamen-china-03-de-setembrode-2017>. Acesso em 17 dez. 2017.

TEMER, M. Discurso do Presidente da República, Michel Temer, durante Cerimônia de Encerramento do Seminário sobre Oportunidade de Investimento - Pequim-China. 2017d. Disponível em: <http://www.itamaraty.gov.br/pt-BR/discursos-artigos-e-entrevistas-categoria/presidente-da-republica-federativa-do-brasil-discursos/17381-discurso-do-presidente-da-republica-michel-temer-durante-cerimonia-de-encerramento-do-seminario-sobre-oportunidadede-investimento-pequim-china-02-de-setembro-de-2017>. Acesso em $17 \mathrm{dez} .2017$.

TZOGOPOULOS, G.N. Time to reappraise the value of Sino-EU ties. Global Times. 2017. Disponível em: <http://www.globaltimes.cn/content/1064710.shtml>. Acesso em 17 dez. 2017.

WALT, Stephen M. 1985. Alliance formation and the balance of world power. International security, v. 9, n. 4, p. 3-43.

WANG, Y. Remarks by Foreign Minister Wang Yi at the Opening Ceremony of ChinaCELAC Economic and Trade Cooperation Forum and China-LAC Business Council Annual Meeting 2018. 2018. Disponível em < http://www.chinacelacforum.org/eng/zyxw 1/t1529775. $\underline{\text { htm }}>$ Acesso em 31 jan. 2018.

WILDAU, G.; MA, N. In charts: China's Belt and Road Initiative. Financial Times. 2017. Disponível em: <https://www.ft.com/content/18db2e80-3571-11e7-bce4-9023f8c0fd2e >. Acesso em 17 dez. 2017.

XI JINPING. Discurso de Xi Jinping na abertura do $19^{\circ}$ Congresso do Partido Comunista da China. 2017. Disponível em: <http://operamundi.uol.com.br/conteudo/geral/48290/leia+inte gra + do + discurso + de $+x i+$ jinping + na + abertura + do $+19+$ congresso + do + partido + comunista + da+china.shtml>. Acesso em 17 dez. 2017. 